March, 1938

\title{
PENNSYLVANIA RULES GOVERNING THE ALLOCATION OF RECEIPTS DERIVED BY TRUSTEES FROM WASTING PROPERTY
}

\section{ROBERT Brigham $\dagger$}

The term "wasting property" has been concisely defined as designating "such interests as terminate or necessarily depreciate in course of time either because of the nature of the interest or because of the character of the subject matter of the interest." 1 For example, an estate per autre vie is wasting property because of the nature of the estate. It necessarily terminates upon the death of the cestui que vie. A mineral lease is wasting property because of the character of the subject matter. Royalty payments cease upon the exhaustion of the minerals.

When wasting property is held in trust, the rule adopted by the Restatement of Trusts ${ }^{2}$ does not allow the trustee to pay out the entire receipts from such property to the income beneficiary unless such payments are authorized by the terms of the trust, interpreted in the light of the circumstances surrounding the creator. In the absence of such authorization, the trustee is required either to sell the property or else to amortize it by retaining sums sufficient to protect the remaindermen against depreciation.

With one or two relatively minor exceptions, the Pennsylvania courts have not adopted any such equitable rule. Curiously enough, the same courts which have spurned convenient but arbitrary rules for the solution of other controversies between income beneficiary and remainderman ${ }^{3}$ have in this instance been inclined to award a disputed fund entirely to income or to principal without, perhaps, realizing that it might be apportioned. The explanation for this situation appears to be largely historical. At an early date our courts were called upon to determine whether, and to what extent, a legal life tenant was permitted to take coal and other minerals from the land. The rules established by these decisions were applied by analogy to coal lands held in trust and finally to other forms of wasting property such as timber lands. Other attempted applications of this analogy will be mentioned in due course.

It very quickly became settled that a legal life tenant of a tract on which there was an open mine had the right to mine the coal, even to exhaustion, and

\footnotetext{
† B. A., I92I, Yale University; LL. B., I929, University of Pennsylvania; member of the Philadelphia Bar; author of Pennsylvania Rules Governing the Allocation of Receipts Derived by Trustees from Shares of Stock (I937). 85 U. of PA. L. REv. 358.

I. Restatearent, TRUSTS (I935) \$239, comment $a$.

2. Id. \$239.

3. E. g., Nirdlinger's Estate, 290 Pa. 457, r39 Atl. 200 (I927), which is typical of the traditional Pennsylvania approach to the problem there under consideration.
} 
the remainderman was without redress. ${ }^{4}$ The life tenant had no such right unless the mine had been opened during the lifetime of the testator ${ }^{5}$ but apparently the remainderman had the burden of showing that no such mine had been opened. ${ }^{6} \quad A$ fortiori, the life tenant is entitled to royalties derived from a mineral lease originally owned by the testator. ${ }^{7}$ The life tenant was, however, subject to restraint for "unskilful mining and wanton injury to the inheritance", 8 and his right to mine was restricted to the particular tract on which the mine had been opened in the lifetime of the testator. ${ }^{9}$ Within these limits, he was not restricted to the quantity or methods of mining conducted by the testator. He could open new pits ${ }^{10}$ or he could make a contract with a corporation under which mining operations, greatly increased by more modern methods, could be carried on. ${ }^{11}$ So long as the operation was subject to no other objection than its liability to exhaust the mine, the courts would not interfere. In effect, the coal was the absolute property of the life tenant, to the extent that he removed it during the life estate.

These rules, developed in connection with legal life estates, were then applied to trusts because they produced a result which the courts believed the creator of the trust presumably intended. When a trustee holds a mineral lease originally owned by the creator of the trust, the entire royalties derived therefrom are income even though the lease is in reality a sale of the minerals and the royalties are part of the consideration. ${ }^{12}$ And if there was an open mine upon the property at the creation of the trust, royalties under a lease made by the trustee are wholly income. ${ }^{13}$ Even though no mining had been done prior to the creation of the trust, if the trustee was given an express power to execute a mineral lease, the royalties derived from a lease made by the trustee are income, ${ }^{14}$ unless the terms of the trust require such royalties to be held as principal. ${ }^{15}$ The grant of express power to the trustee to make a mining lease is treated as the equivalent of the opening of the mines by the creator of the trust.

4. Neel v. Neel, Ig Pa. 323 (1852) ; Irvin v. Covode, 24 Pa. I62 (I854) ; Sayers v. Hoskinson, Iro $\mathrm{Pa} .473$, I Atl. 308 (I885).

5. Blakely v. Marshall, I74 Pa. 425, 34 Atl. 564 (I896).

6. See Lynn's Appeal, 31 Pa. 44, 46 (I857) ("The presumption is in favour of the tenant for life until the contrary appears.").

7. Blodgett's Estate, $254 \mathrm{~Pa}$. 210, 98 At1. 876 (I9I6).

8. Irvin v. Covode, $24 \mathrm{~Pa}$. I62, I67 (I854).

9. Westmoreland Coal Co.'s Appeal, 85 Pa. 344 (1877) ; see McFadden's Estate, $224 \mathrm{~Pa}$. $443,447,73$ At1. 927,928 (I909).

10. Neel v. Neel, I9 Pa. 323 (I852).

II. Irvin v. Covode, $24 \mathrm{~Pa}$. 162 (1854).

I2. McClintock v. Dana, 106 Pa. 386 (I884); Woodburn's Estate, I38 Pa. 606, 2I At1. I6 (I89I) ; Blodgett's Estate, 254 Pa. 210, 98 Atl. 876 (Ig16).

13. See McFadden's Estate, 224 Pa. 443, 447, 73 Ati, 927, 928 (1909).

14. Eley's Appeal, 103 Pa. 300 (1883) ; Shoemaker's Appeal, 106 Pa. 392 (1884) ; Bedford's Appeal, I26 Pa. II7, I7 Atl. 538 (I889).

15. Sharps's Estate, I55 Pa. 289, 26 At1. 44I (I893). 
There may be some basis for the argument that, because the creator of the trust conferred an express power upon his trustee to execute a mineral lease, he intended the income beneficiary to receive the entire royalties even though this might subject the remainderman to more or less risk of impoverishment. But the cases did not stop there. Even though the trust instrument said nothing whatever about a mineral lease, the same result followed if the trustee was given a general power to sell or lease real estate. ${ }^{16}$ The entire royalties derived from a mineral lease made by a trustee pursuant to such a power are awarded to the income beneficiary.

The principles established by these decisions have become rules of property in Pennsylvania. ${ }^{17}$ They apply not only to coal mines ${ }^{18}$ but also to limestone ${ }^{10}$ and slate ${ }^{20}$ quarries and oil and gas wells. ${ }^{21}$ An early case extended them by analogy to timber lands so as to allow a life tenant to cut and sell timber where it appeared that the land was valuable chiefly for its timber and the testator had engaged in timbering operations. ${ }^{22}$ In a very recent case, the proceeds of a timber contract, made by the trustee, were held to be income merely because the trustee was given unrestricted power to sell, lease, and manage the real estate. ${ }^{23}$ In that case, however, the contract forbade the cutting of trees having less than a specified diameter under the bark at the point of cutting, a provision which had for its object the promotion of new growth. If, in addition to such a requirement, the trustee makes provision for adequate reforestation, the award of the proceeds of the timber to the income beneficiary will do the remainderman no harm. Under such circumstances, the growing timber bears a closer analogy to growing crops than to deposits of coal or other minerals.

All of these decisions purport to carry out the actual or presumed intention of the creator of the trust. It may very well be the case that, where a testator was himself engaged in mining or timber operations or derived revenue from a mineral lease, he regarded the proceeds as income and intended that they should be considered as income of his estate. Even though the lands were totally unexploited, the fact that he gave his trustee an express power to exploit them may be some evidence of a like intent. But,

I6. Wentz's Appeal, I06 Pa. 30 (I884) ; McClintock v. Dana, ro6 Pa. 386 (I884).

I7. See McFadden's Estate, 224 Pa. 443, 447, 73 Atl. 927, 928 (I909); Krox's Estate (No. I), $328 \mathrm{~Pa}$. I77, I83, I95 Att. 28, 31 (1937).

I8. Neel v. Neel, Ig Pa. 323 (I852); Irvin v. Covode, 24 Pa. I62 (I854) ; Lynn's Appeal, 3I Pa. 44 (1857) ; Westmoreland Coal Company's Appeal, 85 Pa. 344 (I877); Eley's Appeal, I03 Pa. 300 (1883) ; Wentz's Appeal, I06 Pa. 301 (1884); McClintock v. Dana, I06 Pa. 386 (I884); Shoemaker's Appeal, I06 Pa. 392 (I884); Bedford's Appeal, r26 Pa. II7, I7 Atl. 538 (I889); Sharps's Estate, I55 Pa. 289, 26 Atl. 44I (I893); McFadden's Estate, 224 Pa. 443, 73 Atl. 927 (I909); Blodgett's Estate, 254 Pa. 210, 98 Atl. 876 (I9I6).

19. Lynn's Appeal, 3r Pa. 44 (I857).

20. Sayers v. Hoskinson, I10 Pa. 473, I Atl. 308 (1885).

21. Woodburn's Estate, I38 Pa. 606, 21 Atl. I6 (I89r); Blakely v. Marshall, I74 Pa. 425, 34 Atl. 564 (1896).

22. Williard v. Williard, $56 \mathrm{~Pa}$. II9 (I867).

23. Geyelin's Estate, 29 Pa. D. \& C. 296 (Orph. Ct. 1937). 
it seems very difficult to say that he intended any such result where he merely gave his trustee a general power to sell, lease or manage real estate. The true effect of such a general power is to allow the trustee to execute a coal or oil lease or a contract for the cutting of timber, without being guilty of breach of trust. It should not follow that the entire proceeds of such a contract are income merely because the contract was not a wrongful act on the part of the trustee. The trustee has sold what was not only the capital of the trust but also the capital of the testator, and the nature of the asset is not changed by the fact that the trustee was given a power to sell it. The remainderman would seem to be entitled to some protection against depletion, unless the terms of the trust provide otherwise, either expressly or by clear implication.

However, there is now no possibility that our courts will follow the principles advocated by the Restatement of Trusts, at least as applied to coal or oil royalty payments. ${ }^{24}$ On the contrary, the tendency is rather to extend our own rules. A striking illustration of this is found in the case where the creator of the trust, instead of owning coal or oil lands or royalty contracts, owned stocks in mining or oil companies, which stocks are rightfully retained by the trustee. Ordinary dividends, if paid out of earnings, should be awarded to the income beneficiary under the established rules governing the allocation of dividends. ${ }^{25}$ However, it has been thought that an extraordinary dividend of a mining or oil company should be awarded as principal to the extent that the remaindermen could show that such an award was necessary because the corporation had not built up a depletion reserve, ${ }^{26}$ even though operations were commenced prior to the creation of the trust. Recent

24. In Knox's Estate (No. I), 328 Pa. I77, I86, 195 At1. 28, 33 (1937), the Supreme Court commented on Section 239 of the Restatement: "While the Pennsylvania rule of property, above mentioned, has not been adhered to in the Restatement, under the firmly established principle of stare decisis, we are not now in a position to depart from this rule in a matter of such great importance on the faith of which large property rights have been predicated. For this reason it would be unavailing to embark upon a discussion of the merits or demerits of the principle enunciated by the Restatement."

25. Opperman's Estate (No. I), 3I9 Pa. 455, I79 At1. 729 (1935) ; see Waterman's Estate, 279 Pa. 49r, 496, 124 Atl. I66, I68 (1924).

26. See Harkness's Estate, 5 Pa. D. \& C. 35I, 352 (Orph. Ct. I924), aff'd on other points, $283 \mathrm{~Pa}$. 464, I29 Atl. 458 (I925). The court will award to corpus such portion of an extraordinary dividend as is necessary to preserve the intact value of the shares of a mining company. Waterman's Estate, 279 Pa. 49I, I24 Atl. I66 (I924) (dividend paid in part out of earnings accumulated by the corporation prior to the death of the testator). See also the following cases which involved mining, oil or gas companies: Wittmer's Estate, $283 \mathrm{~Pa}$. 3II, I29 At1. 85 (1925); Mallory's Estate, 285 Pa. I86, I3I Atl. 7I4 (I926) ; Bullitt's Estate, 308 Pa. 413, I62 Atl. 288 (1932); Flinn's Estate, 310 Pa. 206, I65 Atl. 31 (I932). In Nirdlinger's Estate (No. I), 327 Pa. I60, I69, I93 Atl. 33, 37 (I937), the court said: "Cash disbursements by 'wasting asset' companies, engaged in businesses necessitating the consumption and ultimate exhaustion of their assets in order to operate at a profit, have been apportioned as extraordinary dividends where they represent, in part at least, distribution of the proceeds of capital assets. Such corporations are permitted to declare dividends out of surplus without making any deduction for depletion in their assets caused by normal business operations. See Act of May 5, 1933, P. L. 364, \$ 70I, subd. C [PA. Stat. AnN. (Purdon, 1938) tit. 15, $\$ 2852-70$ I (C) ]. In these cases apportionment is a vital necessity to the preservation of intact value." 
cases throw some doubt upon this question because the courts have applied the familiar rules governing coal royalties to dividends of mining corporations whose shares are held in trust, without making it clear that this extension was not intended to apply to extraordinary dividends.

The first decision of this character, Roberts's Estate, ${ }^{27}$ involved a case where the testatrix was the owner of stocks of several close family corporations, each of which owned a single coal mine. Dividends, treated by the auditing judge as extraordinary, were received by the trustees and awarded as income because of the interpretation placed by the auditing judge upon the will. The court en banc, while not disagreeing with the auditing judge, held that the same result could be reached on other (and presumably preferable) grounds, saying:

"Now, it is clear that if the testatrix had been herself the owner of these coal mines, and had devised them to certain persons for life, with remainder to others, the life-tenarits would have been entitled to the entire income derived from royalties on the coal mined, even if the leases ran to the exhaustion of the coal. This is settled in Pennsylvania, and, as it has been frequertly said, has become a rule of property established by a long series of decisions . . . . The same result should follow if the testator, instead of being the sole owner of the mines, was a tenant in common with others, and it is immaterial that the gift was made in the form of a trust . . . . This being so, the fact that her interest was represented by shares of stock in the mine-owning companies is really immaterial, especially in view of the fact that she empowered her trustee to retain the investment. Equity regards the substance and not the form, or, to use a homely metaphor, will crack the shell to get at the kernel, and the fact that the owners of these coal properties put them in corporate form is merely a matter of administrative detail. . . . There is no reason apparent to us why we should not determine here that these dividends, being derived exclusively from royalties on coal taken from mines open at the death of the testatrix, belonged, as such, to the life tenants . . .." 28

Once again the court applied the same test: Was the mine opened during the lifetime of the creator of the trust? If so, its subsequent earnings, in the form of corporate dividends are entirely income whether or not the corporation maintains a depletion reserve. Indeed, the supreme court, in Knox's Estate (No. I), ${ }^{29}$ has just applied the same test to a case where a

27. 2 Pa. D. \& C. 667 (Orph. Ct. I923).

28. Id. at 672. The opinion of the court en banc, from which this language is taken, was written by Gest, J. In Waterman's Estate, 3 Pa. D. \& C. 442 (Orph. Ct. I923), the dissenting opinion of Gummey, $J$., in which Gest, J., concurred, pointed out, at page 447, that the dividends involved in Roberts's Estate ". . . were not declared as extraordinary dividends, but, on the contrary, as to the particular corporation declaring them, were the usual and ordinary ones". Inasmuch as the dividend in Waterman's Estate was extraordinary and had been paid out of earnings accumulated prior to the death of the testator, the dissenting judges thought that it should be awarded to principal, a view which was sustained by the Supreme Court. Waterman's Estate, $279 \mathrm{~Pa}$. 49r, I24 Atl. I66 (1924).

29. $328 \mathrm{~Pa}$. 177, I95 At1. 28 (I937). 
mining corporation declared dividends out of the depletion reserve. Actually, that case involves a very striking extension of the rule. The testator, instead of holding shares of stock in a close family mining company, originally owned 1600 out of a total of over $1,000,000$ outstanding shares of the Cerro de Pasco Copper Corporation, a large mining corporation whose shares are listed on the New York Stock Exchange and widely distributed. To disregard the entity of such a corporation and treat the testator as the owner of an undivided interest in a mine is, to say the least, startling. However, the opinion relies upon the above quoted principle from Roberts's Estate and states in very broad and unrestricted language that dividends received by a trustee from stock of a mining corporation are income whether or not the corporation maintains any depletion reserve, where the testator originally owned the stock and the mines were opened in his lifetime.

The dividends involved in Knox's Estate were regular or ordinary, as distinguished from extraordinary dividends. The remaindermen recognized the rule that ordinary dividends are income if paid out of earnings, but argued that these dividends were paid out of the depletion reserve and were therefore not paid out of earnings. The decision of the court, awarding these particular dividends as income, will probably coincide with the intent of the average testator provided the rule there laid down is confined to ordinary dividends. It will mean only that ordinary dividends of a mining corporation may be considered to have been paid out of earnings even though the corporation has maintained no depletion reserve. Indeed, as to such dividends there is no compelling reason to require the mines to have been opened during the lifetime of the testator. But if the decision applies as well to extraordinary dividends, it will have far reaching consequences, including the repudiation of principles laid down by the supreme court itself only a few months previously. ${ }^{30}$

In that event, there is no logical reason why the court might not go considerably further, if the analogy to coal royalties is to be pressed to its conclusion. Even if the mines were not opened by the corporation before the death of the testator, it doubtless had the corporate power to do so. When the corporation exercises this power to open new mines, it could be argued that any resulting extraordinary dividends are income by analogy to royalties received by a trustee who executes a mineral lease pursuant to an express testamentary power. ${ }^{31}$ Under the broad language of the opinion in Knox's Estate it could be argued that extraordinary dividends, paid out of the earnings of mines opened by the corporation after the death of the testator, would be income of the trust estate even though the corporation maintains no reserve for depletion. Finally, suppose the testator, although

30. See Nirdlinger's Estate (No. I), 327 Pa. I60, I69, I93 At1. 33, 37 (I937).

3r. See cases cited supra note I4. 
owning no stocks of mining corporations, gave his trustee unrestricted power to invest in corporate stocks and the trustee purchased stocks of mining corporations. Are extraordinary dividends received by the trustee to be awarded entirely as income, by analogy to royalties received from a coal lease executed by the trustee pursuant to a testamentary power? At this point, it seems clear, the analogy should break down. Dividends on mining stocks purchased by the trustee should be treated in the same manner as dividends on stocks of other corporations and the remaindermen should be entitled to have extraordinary dividends awarded to corpus to the extent shown to be necessary to protect them against depletion.

It cannot be said at this time how far the courts will apply the analogy of coal royalties to other forms of wasting property received by the trustee from the creator of the trust but it is likely that the analogy will be applied to patent and copyright royalties. In other jurisdictions, it is recognized that copyright royalty payments partake of the nature both of income and principal and should therefore be apportioned. ${ }^{32}$ It may be doubted whether Pennsylvania will adopt any such rule.

Apparently the only reported Pennsylvania case in which copyright royalties were involved was Foster's Estate. $^{33}$ In that case, the testator left his estate to his widow for life with remainder to his brother and sister. The widow was named executrix. The testator wrote several books upon which he received royalties from the publisher during his life. After his death the royalties were collected by the widow as executrix. Not having filed her account as executrix, the widow was cited to do so and the resulting account was referred to an auditor to pass upon the exceptions of the remaindermen. One of the exceptions concerned certain copyrights and the royalty payments received therefrom by the executrix. The testimony showed that the royalty payments fluctuated considerably from year to year but, notwithstanding this fact, the auditor valued the copyright at $\$ 5,000$ and held that the executrix was liable to a cash surcharge in that amount. Obviously this was wrong because the executrix had not received any such sum and the supreme court correctly reversed the surcharge. Although this was the only point actually decided, the opinion indicates that royalty payments received during the life estate are wholly income, the court saying:

"The royalty right was not sold or disposed of by the widow and is properly an asset of the decedent's estate. The most that the resid-

32. For a very full discussion of the problem, see Matter of Elsner, 210 App. Div. 575, 206 N. Y. Supp. 765 (4th Dep't, 1924). The opinion does not clearly indicate the precise method of apportionment, although it suggests that a valuation be placed upon the copyright. Presumably, the income beneficiary would be allowed interest on that valuation, at the average rate produced by the trust investments, and the balance of the royalty payments would be treated as principal. The particular case was relatively simple because, when the case came before the court, the copyright had ceased to return substantial royalties. A valuation could therefore be based upon actual, rather than anticipated, experience.

33. $324 \mathrm{~Pa} .39$, I87 Atl. 399 (1936). 
uary legatees [remaindermen] are entitled to is this same asset. It was error, therefore, to surcharge the executrix with any fixed sum for this item of the decedent's property. The residuary legatees will receive all to which they are entitled if an assignment is made to them in proper form so as to give them in the future ${ }^{34}$ the right to such royalties as may accrue under the contract which the decedent made with Ginn \& Company." 85

The last sentence, which indicates that copyright royalty payments are entirely income as a matter of law was not, of course, necessary to the decision. Regardless of the proper allocation of the royalty payments when received, it would not follow that the executrix would be charged at the outset with the valuation of the copyright itself. Any surcharge because of improper handling of the royalty payments would be measured by the amount of royalty payments which the executrix improperly failed to apportion to principal. No question of proper or improper allocation of royalty payments was before the supreme court. In the court below, however, the auditor considered the proper allocation of the royalty payments received during the life estate and held, on the analogy to coal royalties, that they belonged to the life tenant. ${ }^{36}$ No appeal was taken by the remaindermen and consequently the question was no longer involved in the case when it reached the supreme court. The above quoted language should be read, and perhaps limited, in the light of the exact point which the court was called upon to decide.

Efforts of counsel to extend the coal royalty analogy have not, however, met with uniform success. Sometimes the court has gone to the other extreme and held that the receipts in question were entirely principal. In Jones's Estate $^{37}$ the testatrix, having survived her husband, became entitled to receive $\$ 100$ per month for 300 months upon a policy of insurance upon the life of her husband of which she was beneficiary. After the death of her husband the testatrix received these monthly payments up to the date of her own death. On her death her executor exercised an option to commute the unpaid installments by taking their present worth and received nearly $\$ 18,000$ which was turned over to the trustee under the will. Counsel argued

34. The life tenant having died pending the proceedings, the remaindermen were presently entitled to the assignment.

35. Foster's Estate, 324 Pa. 39, 48, I87 Atl. 399, 403 (I936).

36. See Auditor's Report, Record page 558a, Foster's Estate, 324 Pa. 39, I87 Atl. 399 (1936), in which the auditor said: "The Examiner and Auditor has not been able to find any case wherein royalty from a copyright such as the one owned by the decedent, has been considered from the standpoint of whether the royalty received was corpus of the estate or income. Royalty received under a mining lease, or rentals derived therefrom, are considered to be income in Pennsylvania (Bedford's Appeal, I26 Pa. II7). Under our determination of the intent of the testator, hereinabove expressed, and the analogy to royalties received from mines, the royalties paid by Ginn \& Company are 'proceeds', or income, to which the life tenant is entitled."

37. $97 \mathrm{~Pa}$. Super. 548 (1930). 
that these monthly payments were analogous to coal royalties and should be awarded to income whether or not the installments were commuted. The court very properly held that the commuted sum was entirely principal but quoted with approval the following language from the opinion of the court below, which indicated that even if the trustee had not exercised its option to commute, the monthly installments would have been entirely principal:

"The liability of the insurance company was fixed at a definite amount at the death of the testatrix. That amount was invariable, but was subject to discount or commutation. The monthly payments went to the depletion of the asset. They constituted part payment of the principal, partial satisfaction of the liability of the company. Upon completion of three hundred payments the asset was exhausted and the liability of the insurer was fully satisfied. The monthly payments represented no product of a principal, no derivation therefrom, but invariably resulted in the impairment and depletion of the balance then remaining unpaid." 38

Although the decision of the court was right because the trustee commuted the payments and received their present worth in cash, the above quoted language of the opinion would not do justice to the income beneficiaries if the trustee had elected to receive the payments in installments. If the installment payments were treated as being entirely principal, they would not produce any income until they had themselves been invested by the trustee. At the rate of $\$ \mathrm{IOO}$ a month it would obviously take considerable time to build up a fund large enough to produce a substantial income. The result would be that the estate would hold an asset having a present value of nearly $\$ 18,000$ but which for a long period of time would yield an extremely small amount of income. The injustice to the income beneficiary is manifest and this injustice would be aggravated in case the income beneficiary should die within a few years. If the trustee had elected to receive the payments in installments, a more equitable method of procedure would have been to determine the present worth of the payments, ascertain what income a principal sum of that amount would produce and apportion the payments by giving to the income beneficiary the amount of income so determined, and retaining the balance of the payments as principal of the estate. However, by commuting the payments and receiving their present value in cash which became immediately available for investment, the trustee accomplished at least as favorable a result for the life tenants without in jury to the remaindermen. This should be done by the trustee in any case where the present value of the asset can be ascertained as a mere matter of arithmetic and can be realized in cash without a speculative sale. 
Where these conditions did not exist, the method which was adopted by the Orphans' Court of Philadelphia in Lennig's Estate ${ }^{39}$ has much to recommend it. In that case one of the assets of the trust was an interest in income derived from another estate. These payments would continue, however, only during the life of a certain Mrs. Thudicum. Stated in more technical language, the testator was a tenant per autre vie and Mrs. Thudicum was the cestui que vie. The testator left this interest, as tenant per autre vie, to his trustee. The orphans' court, after pointing out that it would be unfair to the remaindermen to hand over all of the payments to the income beneficiaries, who would consume the entire asset if they should survive the cestui que vie, held that it would be equally unfair to the income beneficiaries to treat all of the payments as principal. In the latter case, as pointed out by the court, the life expectancy of the cestui que vie may be long whereas the life expectancy of the income beneficiaries may be short and if the payments were treated as principal the result would be that the estate would have an asset of large value yielding the income beneficiaries an inconsequential return. Nor could it be said that the trustee was obliged to sell this asset because a sale could perhaps be made only upon a highly speculative basis. The court, therefore, directed the apportionment of the payments in accordance with the following principles:

"Under such circumstances, we are of opinion that this asset should be appraised and its value approximated as of Nov. 5, I9I4, one year after death of testator. In doing this, regard should be had to the age of Mrs. Thudicum, her life expectancy, the amount which will accrue annually from the estate of Charles Lennig, the current rate of return on trust investments, \&c. When the value of this asset has been thus ascertained and the rate of return for trust investments fixed, there should be awarded to the life-tenants, for the life of Mrs. Thudicum, yearly interest on the value and at the rate thus ascertained. Upon the death of Mrs. Thudicum, it will be possible to ascertain accurately the present worth of this asset as of the death of John B. Lennig, and upon this value the life-tenants will be entitled to yearly interest at the prevailing rate for trust investments. Until that time arrives, or the asset sold, the method pointed out above will work an equitable result as between the parties, which later can be translated into accurate terms and thereupon finally adjusted." 40

This case appears to be the only reported decision of a Pennsylvania court which approaches the problem in the same way as does the Restatement of Trusts. ${ }^{41}$ However, two judges dissented on the ground that the testator had the right to these payments on his death and consequently the

39. $30 \mathrm{~Pa}$. Dist. 320 (Orph. Ct. I92I).

40. Ibid.

4I. Restatement, Trusts (1935) § 239. 
payments, when collected by the trustee, were entirely principal. ${ }^{42}$ Subsequent history indicates that, on the death of the cestui que vie, an actuarial computation of the value of the asset was submitted to the court, with the result that the principal value of the asset was "translated into accurate terms" and the rights of the life tenants and remaindermen were finally adjusted. ${ }^{43}$ Nor was any unusual difficulty encountered in so doing.

Another form of wasting property which has been considered by our courts is the premium upon a bond. If a bond is received from the creator of the trust, or purchased by the trustee, when it sells above par, the premium is a wasting asset. Theoretically, it decreases each year until it vanishes altogether when the bond is paid off at maturity at par.

In the case of a trustee who is not authorized to retain securities not designated by statute as legal investments, it is dangerous for the trustee to receive such a bond from the creator of the trust at a time when it sells at a large premium and retain it until it is paid off at par. The trustee may find himself surcharged for the lost premium unless he can show that the bond could not have been sold promptly. ${ }^{44}$ However, a trustee may pay a premium for an otherwise proper investment and will not be surcharged merely because the bonds were unexpectedly called for redemption at $\operatorname{par}^{45}$ or because the bonds were held until maturity. ${ }^{46}$

In many jurisdictions, premiums paid for investments made by the trustee are required to be amortized by periodic charges against income in order to protect the remaindermen against depreciation of the premium. ${ }^{47}$ At an early date, the Orphans' Court of Philadelphia took the position that such premiums should not be amortized out of income. ${ }^{48}$ This rule was subsequently approved by the superior ${ }^{49}$ and supreme ${ }^{50}$ courts and, with a qualification hereafter to be noted, has become the settled law of Pennsylvania. It would be unprofitable at this late date to discuss at much length the relative desirability of our rule as contrasted with the rule of amortization which has found favor in other jurisdictions. The truth probably is that "no rule on this subject can be stated that in all cases will produce an equitable result." 51 One of the principal arguments in support of our rule is that the amortization may penalize the income beneficiary in order to protect

42. 30 Pa. Dist. 320, 325 (Ig2r).

43. See record of Lennig's Estate, Orph. Ct. Phila., October Term, 19r4, No. 564.

44. Taylor's Estate, $277 \mathrm{~Pa}$. 518, I2I At1. 3ro (1923).

45. Cridland Estate, I32 Pa. 479, I9 Atl. 362 (I890).

46. Lafferty's Estate, $23 \mathrm{~Pa}$. Dist. 327 (Orph. Ct. I9r4). However, a trustee would be surcharged for "improvident purchase of long term loans at high premiums to avoid care and responsibility." Penn-Gaskell's Estate (No. 2), 208 Pa. 346, 349, 57 At1. 715, 716 (I904).

47. See cases collected in Notes (I9I9) 4 A. L. R. I249, (I922) I6 A. L. R. 527. The mathematical aspects of the problem are treated in elaborate detail in Note (I936) Ior $A$. L. R. 7 .

48. Furness's Estate, I2 Phila. I30 (Orph. Ct. I878).

49. Boyer v. Chauncey, I2 Pa. Super. 526 (I900).

50. Penn-Gaskell's Estate (No. 2), 208 Pa. 346, 57 At1. 7 I5 (I904).

51. Id. at 348, $57 \mathrm{Atl}$. at 716 . 
the remaindermen against a loss that may never occur. The income beneficiary may die or the security may be sold before any depreciation has taken place. Moreover, the courts have felt that the premium is most frequently paid for the sake of the security of the investment rather than for the purpose of enlarging the income and therefore should be charged against principal. The latter argument caused the supreme court to say, purely by way of dictum:

"If premiums were paid to secure greater income, they should be charged of course to the life tenant, because he could be the only party benefited by the payment." 52

This dictum was followed by the Orphans' Court of Philadelphia in Catherwood's Estate. ${ }^{53}$ In that case, the trustee held bonds bearing interest at the respective rates of $5,4 \frac{1}{2}$ and 4 per cent. These bonds had been purchased at premiums and had not yet matured. The trustee had also paid premiums for bonds bearing interest at 7.3, 7 and 6 per cent respectively but these bonds had matured and had been paid off at par. The court held that the latter premiums should be charged entirely against income and that the former should be charged entirely against principal. It seemed apparent to the court that, considering the usual return that could be expected from trust investments, bonds paying a higher rate than 5 per cent had been purchased primarily to secure a larger return and therefore the premiums had been paid for the benefit of the life tenant.

Except in a more or less arbitrary manner, it is difficult to determine when the premium was paid for the purpose of enlarging the income and when it was paid for the security of the investment. The court in Catherwood's Estate really considered only one of the factors which determine the price of a bond. Actually, the price is determined by many factors, including the credit standing of the obligor and the security behind the obligation, the coupon rate as compared with the market rate of interest on obligations of similar character, and the date of maturity. Even if it is possible to determine the purpose for which the premium was paid, it does not always follow that the premium should be charged entirely against either income or principal. When the bond is actually paid off at par, as in Catherwood's Estate, so that the loss of premium is in fact incurred during the life estate, the loss might have been divided between income and principal in proportion to the amount which each has received from the investment. ${ }^{54}$

The Pennsylvania rules concerning premiums on investments do not purport to be based upon any actual or presumed intention of the creator of the trust, although Judge Penrose thought that a direction to pay "the

52. Ibid.

53. 22 Pa. Dist. 5I7 (Orph. Ct. I913).

54. See opinion of Penrose, J., in Boyer v. Chauncey, I2 Pa. Super. 526, 527 (1900). 
net income" of the trust to the life tenant was sufficient to prevent the charge of any premiums against income. ${ }^{55}$ It is therefore common practice to give the trustee discretion to purchase investments at a premium and to amortize the premium out of income, a practice which in the opinion of the same eminent judge would result in an illegal accumulation. ${ }^{56} \mathrm{He}$ said:

"It would seem, indeed, whatever may be the law elsewhere, that our statute forbidding accumulation except during an existing minority and for the benefit of the minor, effectually prevents this, for the withholding of any part of the income to create a fund to be applied to the restoration of principal comes directly within the ruling in Washington's Estate, $75 \mathrm{~Pa}$. IO2 [I874], and the numerous cases which have followed it." 57

The case cited by the learned judge did not, however, involve the legality of a provision of this kind, the only purpose or effect of which is to prevent a depletion of principal. Although the validity of a provision in a will or deed of trust authorizing the trustee to amortize bond premiums out of income does not appear to have been expressly decided, it has been stated that "it is not an accumulation merely to replace that which has been worn out or that which might be destroyed" 58 and that "the statute has no relation to maintaining intact the principal of the trust". ${ }^{59}$ More recently, the supreme court, in speaking of the accumulations that are forbidden by the statute, said:

"This term is applied only to income retained for the deliberate purpose of adding it to corpus. Where income is reserved as a separate fund, to meet exigencies which might subsequently arise, and which might otherwise necessitate a depletion of principal, there is no unlawful accumulation. Such an income reserve is, on the contrary, in the interest of judicious management." 60

It would seem, therefore, that the creator of the trust can validly provide for the amortization of bond premiums out of income. Whether or not he can change the rules relating to coal and oil royalties is, perhaps, a more doubtful question. It has been assumed that these rules, being ostensibly principles by which the courts have determined the actual or presumed intention of the creator of the trust, must yield to an actual expression of intent that royalties, which under the established rules would otherwise be treated

55. Id. at 529 .

56. Pa. Stat. AnN. (Purdon, Supp. 1937) tit. 20, § 3251.

57. Boyer v. Chauncey, I2 Pa. Super. 526, 528 (I900). The Superior Court, however, did not find it necessary to pass upon this question.

58. Nax's Estate, I8 Pa. Dist. 423, 425 (Orph. Ct. I909).

59. Stocking's Estate, $304 \mathrm{~Pa} .476,480$, I56 Atl. 79, 80 (I93I).

60. Mathues's Estate, 322 Pa. 358, 360, I85 Atl. 768, 769 (1936). 
as income, should be considered as principal. 61 However, the coal royalty rules have become rules of property. ${ }^{62}$ When rules of interpretation crystallize into rules of property, there is a strong tendency to hold that the creator of the trust cannot, without violating the statute against accumulations, direct the trustee to keep in corpus what would normally be awarded as income. ${ }^{63}$ Nevertheless, if the creator of the trust does not like the rules which the courts have established for determining what is principal and what is income, he should be allowed to prescribe his own rules without fear of the statute against accumulations where, as in the case of wasting property, the application of the ordinary rules may well result in a serious depletion of principal.

The fact is that we have no rules of general application established by our appellate courts, and dealing with the allocation of proceeds derived from wasting property, which give due recognition to the fact that the property is actually wasting. With very few exceptions, the proceeds are awarded either entirely to income or entirely to principal according to circumstances which have no relation to the character of the property. Moreover, our decisions evidence a growing liberality to the income beneficiary ${ }^{64}$ on the theory that he is the principal object of the bounty of the creator of the trust. Under these circumstances, it is not surprising that Judge Penrose, one of our most eminent judges, when pressed by counsel with leading cases from other jurisdictions, said, many years ago:

"But Massachusetts decisions, even when unanimous, and English decisions, in cases involving questions between income and principal . . . are unsafe guides for Pennsylvania lawyers . . . ." 65

6r. Sharps's Estate, I55 Pa. 289, 26 Atl. 44I (I893). The application of the statute against accumulations was apparently not pressed upon the court below in connection with the direction that royalties should be deemed principal and the question was not involved when the case came before the Supreme Court.

62. See McFadden's Estate, 224 Pa. 443, 447, 73 Atl. 927, 928 (1909); Knox's Estate (No. I), 328 Pa. I77, I83, I95 At1. 28, 3 I (I937).

63. Cf. Maris's Estate, 301 Pa. 20, I5I Atl. 577 (I930).

64. Knox's Estate (No. I), $328 \mathrm{~Pa}$. I77, I95 Atl. 28 (I937) is a striking example of this tendency.

65. Boyer v. Chauncey, I2 Pa. Super. 526, 529 (1900). 